\title{
ANALISIS KANDUNGAN LOGAM BERAT Hg DAN Cu TERLARUT DI PERAIRAN PESISIR WONOREJO, PANTAI TIMUR SURABAYA
}

\author{
Syarifah Hikmah Julinda Sari ${ }^{1}$, Jessica Feibe Ambar Kirana ${ }^{2}$, Guntur $^{3}$ \\ Email: syarifahsari@ub.ac.id
}

\begin{abstract}
Abstrak: Penelitian ini bertujuan untuk mengetahui kandungan logam berat $\mathrm{Hg}$ dan $\mathrm{Cu}$ terlarut di badan air Perairan Pesisir Wonorejo, Pantai Timur Surabaya serta menganalisis faktor lingkungan yang mempengaruhinya. Penelitan dilaksanakan pada bulan April 2015 dengan menetapkan tiga titik pengambilan sampel air. Pada setiap titik sampel air diambil pada bagian permukaan, tengah dan dekat dasar perairan. Parameter yang diukur meliputi logam berat terlarut $\mathrm{Hg}$ dan $\mathrm{Cu}$, TSS, suhu, salinitas, $\mathrm{pH}, \mathrm{DO}$, dan turbiditas. Data dianalisis secara deskriptif dan statistik (Analisis Komponen Utama dan Korelasi Pearson). Konsentrasi $\mathrm{Hg}$ dan $\mathrm{Cu}$ pada badan air Perairan Pesisir Wonorejo telah melebihi baku mutu yang ditetapkan, namun konsentrasi parameter lingkungan TSS, suhu, salinitas, $\mathrm{pH}$ dan DO masih tergolong baik. Konsentrasi $\mathrm{Cu}^{2+}$ terlarut cenderung semakin menurun seiring dengan pertambahan kedalaman dan kembali meningkat di dasar kolom air sedangkan konsentrasi $\mathrm{Hg}^{2+}$ terlarut semakin meningkat seiring dengan pertambahan kedalaman. Salinitas merupakan faktor lingkungan yang berkontribusi menentukan keberadaan logam berat terlarut $\mathrm{Hg}$ dan $\mathrm{Cu}$.
\end{abstract}

Kata Kunci : Pencemaran, Perairan Pesisir, Wonorejo, Logam Berat Terlarut

\section{PENDAHULUAN}

Perairan Pesisir Wonorejo merupakan bagian dari Pantai Timur Surabaya yang menerima aliran sungai (DAS) Kali Jagir Wonokromo, Wonorejo dan Gunung Anyar. Seperti halnya perairan pesisir lainnya, Perairan Pesisir Wonorejo berpotensi mengakumulasi beban antropogenik yang dibawa dari tiga aliran sungainya. Hal ini diperparah dengan adanya penyalahgunaan sungai sebagai tempat pembuangan limbah sehingga beban pencemar akan terdistribusi sampai ke muara sungai hingga laut. Masukan limbah dari darat menuju ke muara umumnya berasal dari kegiatan manusia seperti seperti industri, perkapalan, antropogenik dan lain-lain (Bengen, 2001).
Hal tersebut menjadikan daerah muara dan pesisir merupakan kawasan yang rentan tercemar.

Salah satu bahan pencemar yang berpotensi ditemukan di Perairan Pesisir Wonorejo adalah logam berat. Pencemaran logam berat dikategorikan sebagai pencemaran yang menimbulkan dampak yang berbahaya terhadap lingkungan dan organisme di dalamnya. Logam berat mempunyai sifat non-degradable. Selain itu, logam berat akan terakumulasi di dalam lingkungan seperti kolom air dan sedimen serta terabsorpsi ke dalam biota laut (Effendi, 2003).

Pada kolom air, konsentrasi logam berat akan sangat tergantung dengan 
faktor lingkungan. Perubahan nilai konsentrasi logam berat diakibatkan karena perubahan arus, suhu, salinitas, $\mathrm{pH}$, kekuatan ionik, jumlah dan jenis bahan pencemar serta kedalaman. Kedalaman perairan yang berbeda tentunya juga memiliki karekteristik fisika dan kimia yang berbeda. Berdasarkan penelitian yang dilakukan oleh Guliyev et al. (2014), konsentrasi $\mathrm{Cu}$ dan $\mathrm{Zn}$ semakin menurun seiring dengan bertambahnya kedalaman perairan, sedangkan konsentrasi Fe dan Hg semakin meningkat seiring dengan bertambahnya kedalaman perairan. Karakteristik logam berat di perairan yang bersifat dinamis memiliki kaitannya dengan sifat toksisitas logam berat tersebut pada kolom air.

Kehadiran logam berat pada konsentrasi yang tinggi di kolom peraian akan membahayakan organisme perairan laut mulai dari menghambat proses metabolisme hingga menyebabkan kematian biota (Vangronsveld and Clijsters, 1994). Oleh karena itu, penelitian ini bertujuan untuk memantau konsentrasi logam berat terlarut di sepanjang kolom Perairan Pesisir Wonorejo dan menganalisis keterkai-tannya dengan faktor lingkungan per-airan.

Penelitian ini akan fokus pada dua spesies logam berat yaitu $\mathrm{Hg}$ dan $\mathrm{Cu} . \mathrm{Hg}$ merupakan logam berat non esensial, sedangkan $\mathrm{Cu}$ dikategorikan sebagai logam berat essensial. Hg merupakan logam berat paling toksik terhadap organisme, sedangkan $\mathrm{Cu}$ pada konsen-trasinya yang tinggi dapat menyebabkan kematian dan konsentrasi sub letal dapat menyebabkan gangguan berbagai fungsi organ tubuh (Herdianto, 2003).

\section{METODE}

Penelitian ini dilaksanakan pada bulan Maret-Juni 2015. Pengambilan sampel air laut dilakukan pada bulan April 2015 di Perairan Pesisir Wonorejo, Surabaya.. Sebanyak tiga titik pengam-bilan sampel ditetapkan pada penelitian ini (Gambar 1). Titik 1 terletak pada koordinat $7^{\circ} 18^{\prime} 31.39^{\prime \prime}$ LS dan 112 ${ }^{\circ} 11^{\prime 26.65^{\prime \prime}}$ BT, titik 2 terletak pada $7^{\circ} 18 ' 2.74 "$ LS dan $112^{\circ} 51 ' 27.59^{\prime \prime}$ BT, dan titik 3 terletak pada $7^{\circ} 17^{\prime} 35.65^{\prime \prime}$ LS dan 112 $51 ' 25.70^{\prime \prime}$ BT. Setiap titik akan diambil sampel air pada kedalaman permukaan, tengah dan dasar untuk diukur kandungan logam berat terlarut $\mathrm{Hg}$ dan $\mathrm{Cu}$, TSS serta faktor lingkungan. Pengukuran parameter lingkungan seperti suhu, $\mathrm{pH}, \mathrm{DO}$, salinitas, dan turbiditas dilakukan secara in situ dengan menggunakan Chlorotech probe type AAQ 1183 AAQ 1183. Selanjutnya ,analisis laboratorium pengukuran konsentrasi logam berat $\mathrm{Hg}$ dan $\mathrm{Cu}$ menggunakan AAS Shimadzu Atomic Absorption/Flame Spectrophotometer Model AA-6800 dan TSS dilaksanakan di Laboratorium Kimia, Fakultas Matematika dan Ilmu Pengetahuan Alam, Universitas Brawijaya, Malang. 


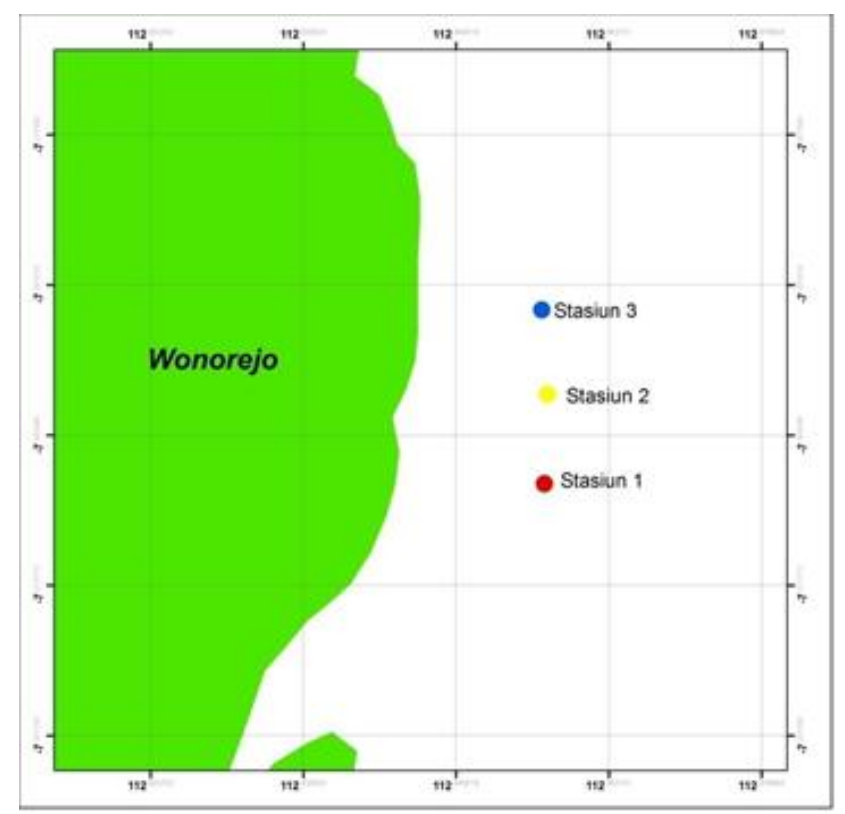

\section{Gambar 1. Lokasi Stasiun Penelitian}

Pengambilan sampel air laut untuk pengukuran konsentrasi logam berat yang terlarut di dalamnya memiliki perlakuan khusus untuk wadah sampel air. Pengambilan sampel air menggunakan botol kaca gelap yang sebelumnya dilakukan proses perendaman mengguna-kan $\mathrm{HNO}_{3}$ selama 48 jam dan dibilas menggunakan aquadest lalu dikeringkan. Menurut APHA Standard Methods (2001), untuk pengawetan sampel air yang akan dianalisis kandungan logam beratnya perlu dilakukan penambahan $\mathrm{HNO}_{3}$ pekat. Setelah sampel diawetkan, sampel dimasukkan ke dalam cool box bersuhu $4-5^{\circ} \mathrm{C}$. Proses pre-treatment dilakukan menurut Hutagalung et al (1997).

Analisis data disajikan secara deskriptif dan statistik. Data konsentrasi logam berat $\mathrm{Hg}$ dan $\mathrm{Cu}$ serta faktor lingkungan disajikan dalam bentuk grafik/tabel yang dilengkapi dengan nilai rata-rata dan standar deviasi. Keterkaitan logam berat $\mathrm{Hg}$ dan $\mathrm{Cu}$ digambarkan me- lalui Analisis Komponen Utama (Principal Component Analysis). Soft-ware yang digunakan dalam analisis data pada penelitian ini antara lain Microsoft Excel 2010 dan SPSS 16.0.

\section{HASIL DAN PEMBAHASAN}

\section{Kondisi Umum Perairan Pesisir Won- orejo}

Secara administratif, Perairan Pesisir Wonorejo terletak di Kelurahan Wonorejo Kecamatan Rungkut, Surabaya Timur. Curah hujan di atas $200 \mathrm{~mm}$ pada saat bulan April 2015. Suhu udara di Pantai Timur Surabaya berkisar rata-rata minimum $23,4^{\circ} \mathrm{C}$ dan maksimum $35,2^{\circ} \mathrm{C}$ dan kelembapan udara rata-rata minimum 42\% dan maksimum $96 \%$.

Pantai Timur Surabaya merupakan pantai landai dengan kemiringan 0-3 dengan rentangan pasang surut 1,67 meter. Tipe pasang surut di perairan Wo- 
4

Syarifah Hikmah Julinda Sari, Jessica Feibe Ambar Kirana, Guntur. Analisis Kandungan

Logam Berat Hg Dan Cu Terlarut Di Perairan Pesisir Wonorejo, Pantai Timur Surabaya

norejo termasuk dalam tipe mixed semi

berbeda. Kondisi faktor lingkungan

diurnal karena terjadi dua kali pasang dan

perairan disajikan pada Tabel 1 .

dua kali surut dengan ketinggian yang

Tabel 1. Kondisi umum Perairan Pesisir Wonorejo

\begin{tabular}{|c|c|c|c|c|c|c|}
\hline \multirow[b]{2}{*}{ Kolom Air } & \multicolumn{6}{|c|}{ Parameter Fisika-Kimia Perairan (rata-rata \pm standar deviasi) } \\
\hline & Suhu $\left({ }^{0} \mathrm{C}\right)$ & $\begin{array}{l}\text { Turbiditas } \\
\text { (NTU) }\end{array}$ & $\begin{array}{l}\text { TSS } \\
\text { (ppm) }\end{array}$ & $\mathrm{pH}$ & Salinitas (\%o) & $\mathrm{DO}(\mathrm{mg} / \mathrm{L})$ \\
\hline Permukaan & $31,82 \pm 0,42$ & $10,44 \pm 1,9$ & $24 \pm 1$ & $9,81 \pm 0,05$ & $21,56 \pm 0,43$ & $11,95 \pm 0,39$ \\
\hline Tengah & $30,30 \pm 0,06$ & $23,78 \pm 15,59$ & $19 \pm 1$ & $9,41 \pm 0,34$ & $25,53 \pm 0,28$ & $6,35 \pm 5,58$ \\
\hline Dasar & $29,91 \pm 0,1$ & $28,64 \pm 16,07$ & $22 \pm 1$ & $9,26 \pm 0,25$ & $26,44 \pm 0,43$ & $5,26 \pm 5,47$ \\
\hline
\end{tabular}

Suhu di perairan pesisir wonerojo berkisar antara $29,91^{\circ} \mathrm{C}$ hingga $31,82^{\circ} \mathrm{C}$. Rata-rata suhu terendah didapatkan pada bagian dasar kolom air sedangkan suhu perairan tertinggi didapatkan pada bagian permukaan laut. Perbedaan suhu dari bagian permukaan hingga dasar kolom air rata-rata sebesar $2^{0} \mathrm{C}$. Saputra (2009) menyatakan bahwa suhu air laut terutama di bagian permukaan mempunyai kaitan yang cukup erat dengan pemanasan matahari dan besarnya intensitas cahaya yang masuk ke dalam perairan. Trend suhu menunjukkan bahwa dengan semakin bertambahnya kedalaman, suhu perairan semakin menurun. Hal ini dikarenakan berbagai faktor lingkungan lainnya seperti intensitas cahaya matahari, sirkulasi arus, kedalaman dan juga musim. Distribusi suhu air laut di suatu perairan dipengaruhi oleh banyak faktor diantaranya ialah radiasi sinar matahari, kedalaman, letak geografis, angin dan musim (Patty, 2013).

Turbiditas pada badan air periaran pesisir wonorejo berkisar antara 10,44 NTU hingga 28,64 NTU. Turbiditas tertinggi didapatkan pada badan air dekat dengan dasar perairan, sedangkan turbidi- tas terendah pada badan air dekat permukaan. Perbedaan turbiditas dari bagian permukaan hingga dasar kolom air ratarata sebesar 18,2 NTU. Trend turbiditas menunjukkan bahwa dengan semakin bertambahnya kedalaman, nilai turbiditas semakin tinggi. Perbedaan nilai turbiditas pada badan air dipengaruhi oleh keberadaan dan jumlah beberapa faktor penghalang intensitas matahari seperti suspended solid, dissolved organic matter dan particulate organic matter termasuk plankton (Sunarto, 2008).

Kandungan TSS yang ditemukan pada badan air Perairan Pesisir Wonorejo adalah 19-24 ppm. Apabila ditinjau dari pengukuran TSS pada bagian permukaan, tengah dan dasar kolom air, maka dapat dilihat bahwa kualitas air di Perairan Wonorejo, Surabaya dalam kondisi yang cukup baik.

pH pada kolom air Perairan Wonorejo didapatkan yang berkisar antara 9,26 hingga 9,81. semakin bertambahnya kedalaman, nilai $\mathrm{pH}$ semakin rendah. Namun, penurunan nilai $\mathrm{pH}$ menurut kedalaman tidak signifikan karena hanya berubah sebesar 0,55 satuan. Faktorfaktor yang mempengaruhi perbedaan 
tersebut antara lain aktivitas biologi, suhu, kandungan oksigen dan ion-ion. Dari aktivitas biologi akan dihasilkan gas $\mathrm{CO}_{2}$ yang merupakan hasil respirasi. Gas inilah yang selanjutnya akan membentuk ion buffer untuk menjaga kestabilan kisaran $\mathrm{pH}$ di perairan (Marganof, 2007).

Salinitas perairan yang berkisar antara $21,56 \%$ hingga $26,44 \%$. Rata-rata salinitas terendah didapatkan pada bagian permukaan air yaitu sebesar $21,56 \%$ sedangkan rata-rata salinitas tertinggi didapatkan pada bagian dasar kolom air yaitu sebesar 26,44\%o. Hal ini dikarenakan Perairan Wonorejo masih sangat mendapatkan pengaruh oleh adanya masukan dari sungai. Salinitas di bagian permukaan cenderung lebih rendah karena adanya pengaruh masukan air yang lebih dari sungai Wonorejo. Semakin bertambahnya kedalaman, nilai salinitas semakin tinggi. Sebaran salinitas di laut dipengaruhi oleh berbagai faktor seperti pola sirkulasi air, penguapan, curah hujan dan aliran sungai. Berbagai faktor inilah yang menimbulkan perbedaan nilai salinitas di setiap kedalaman (Nontji, 1993).

DO pada badan air Perairan Wonorejo didapatkan berkisar antara 5,26 mg/l hingga 11,95 mg/l. Rata-rata DO terendah didapatkan pada bagian dasar kolom air yaitu sebesar $5,26 \mathrm{mg} / \mathrm{l}$ sedangkan rata-rata DO tertinggi didapatkan pada bagian permukaan air yaitu sebesar 11,95 mg/l. Hal ini dikarenakan proses difusi gas oksigen dari atmosfer menyumbang keberadaan oksigen terlarut di badan air dekat permukaan, sebaliknya peningkatan keke-ruhan dan terbatasnya penetrasi cahaya matahari menyebabkan nilai oksigen terlarut lebih rendah pada badan air dekat dasar sedimen. Marganof
(2007) menyatakan sumber DO utama di dalam air adalah oksigen yang terdapat di atmosfer. Berdasarkan baku mutu Keputusan Kementerian Lingkungan Hidup No. 51 Tahun 2004 lampiran 3 tentang baku mutu air laut untuk biota laut, kualitas air laut pada Perairan Pesisir Wonorejo tergolong baik, kecuali nilai turbiditas perairan yang melebihi baku mutu tersebut.

\section{Kandungan Logam Berat $\mathrm{Hg}$ dan $\mathrm{Cu}$}

Konsentrasi logam berat terlarut $\mathrm{Hg}$ dan $\mathrm{Cu}$ disajikan pada Gambar 2. Berdasarkan hasil pengukuran, logam berat terlarut $\mathrm{Hg}$ didapatkan sebesar 0,015-0,017 ppm dengan nilai rata-rata sebesar 0,016 $\pm 0,001 \mathrm{ppm}$. Konsentrasi tersebut tergolong tinggi menurut standar baku mutu air laut dalam Keputusan Menteri Lingkungan Hidup Nomor 51 Tahun 2004 Lampiran 3 tentang Baku Mutu Air Laut untuk Biota Laut sebesar 0,001 ppm. Konsentrasi $\mathrm{Hg}$ pada bagian dasar memiliki konsentrasi yang lebih tinggi. Hal ini dikarenakan $\mathrm{Hg}$ memiliki sifat yang lebih mudah untuk terakumulasi dalam sedimen. Residence time $\mathrm{Hg}$ di perairan dan sedimen jauh lebih lama dibandingkan dengan yang terdapat di daratan dan udara, yaitu masing-masing $32 \times 10^{3}$ pada perairan laut dan $2,5 \times 10^{8}$ pada sedimen (Mokoagouw, 2000).

Logam berat $\mathrm{Cu}$ terlarut pada lokasi yang sama ditemukan sebesar 0,0710,091 ppm dengan nilai rata-rata $0,080 \pm 0,010 \mathrm{ppm}$. Nilai tersebut juga berada di atas baku mutu air laut untuk biota laut. Rata-rata konsentrasi $\mathrm{Cu}^{2+}$ terlarut terendah didapatkan pada bagian tengah kolom air yaitu sebesar $0,071 \mathrm{mg} / \mathrm{l}$ sedangkan rata-rata konsentrasi $\mathrm{Cu}^{2+}$ ter- 
Syarifah Hikmah Julinda Sari, Jessica Feibe Ambar Kirana, Guntur. Analisis Kandungan Logam Berat Hg Dan Cu Terlarut Di Perairan Pesisir Wonorejo, Pantai Timur Surabaya

larut tertinggi didapatkan pada bagian permukaan yaitu sebesar 0,091 mg/l. Konsentrasi $\mathrm{Cu}^{2+}$ terlarut pada ketiga stasiun penelitian cenderung lebih tinggi pada bagian permukaan. Hal ini dikarenakan bagian permukaan air merupakan bagian kolom air yang paling dekat dengan lapisan udara. Sumber $\mathrm{Cu}$ di perairan banyak berasal dari udara yang mengandung $\mathrm{Cu}$ berupa partikulat. Selain itu bagian permukaan air mendapatkan pengaruh paling besar dari limbah aktivitas anthropogenik. Sumber Cu di perairan adalah debu dan atau partikulat-partikulat $\mathrm{Cu}$ yang ada dalam lapisan udara yang dibawa turun oleh air hujan. Secara non alamiah, $\mathrm{Cu}$ masuk ke dalam perairan sebagai limbah dari aktivitas manusia (Surbakti, 2011).

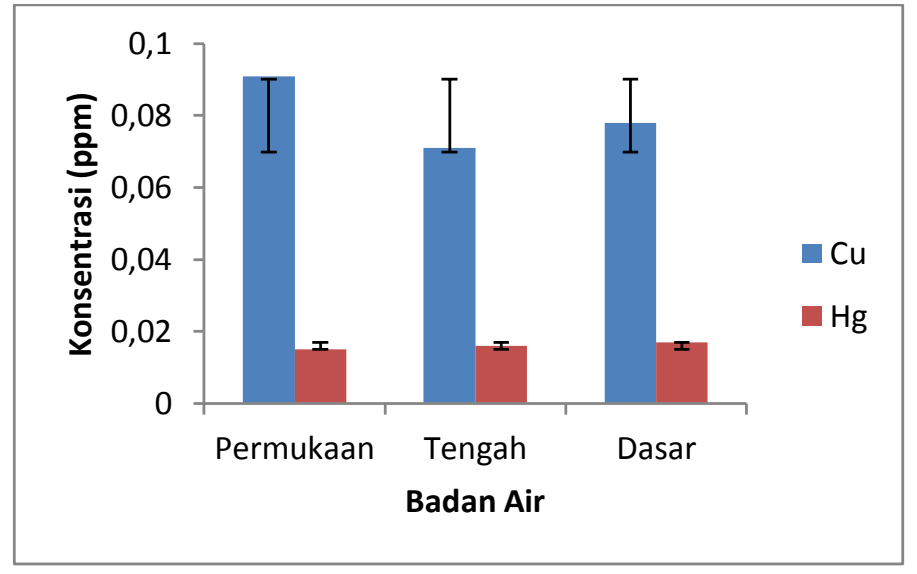

Gambar 2. Konsentrasi Hg dan Cu terlarut di Perairan Pesisir Wonorejo

\section{Keterkaitan Hg dan Cu Terlarut ter- hadap Faktor Lingkungan}

Hasil Analisis Komponen Utama untuk $\mathrm{Hg}$ terlarut pada badan air Perairan Pesisir Wonorejo didapatkan bahwa $\mathrm{Hg}$ terlarut pada permukaan perairan mendapat pengaruh dari nilai $\mathrm{DO}$, sedangkan pada kedalaman tengah kolom air mendapatkan pengaruh yang besar dari salinitas. Kandungan $\mathrm{Hg}$ pada kedalaman dekat dasar mendapatkan pengaruh utama dari parameter turbiditas.
Konsentrasi $\mathrm{Hg}^{2+}$ terlarut lebih banyak ditemukan pada bagian dasar kolom air dikarenakan sifat $\mathrm{Hg}$ yang mudah mengendap pada sedimen dalam bentuk partikulat. Konsentrasi $\mathrm{Hg}$ di kolom air yang terlarut biasanya berjumlah sangat kecil. Ion $\mathrm{Hg}^{2+}$ yang dihasilkan dari perombakan persenya-waan merkuri pada endapan sedimen badan perairan, dengan bantuan bakteri akan berubah menjadi dimetil merkuri $\left(\mathrm{CH}_{3}\right)_{2} \mathrm{Hg}$ dan ion metil merkuri $\left(\mathrm{CH}_{3} \mathrm{Hg}\right)$ (Taftazani, 2007).

Berdasarkan hasil Analisis Komponen Utama untuk $\mathrm{Cu}^{2+}$ terlarut di 
kedalaman berbeda, menggambarkan bahwa konsentrasi $\mathrm{Cu}$ pada kedalaman permukaan mendapatkan pengaruh yang besar oleh TSS. Selanjutnya konsentrasi $\mathrm{Cu}$ pada kedalaman tengah kolom air tidak mendapatkan pengaruh dari parameter lingkungan, sedangkan konsentrasi $\mathrm{Cu}$ pada kedalaman dekat dasar mendapatkan pengaruh yang besar dari salinitas dan turbiditas.

Distribusi $\mathrm{Cu}$ yang berubah naik turun disebabkan oleh berbagai proses fisis air. Proses fisis yang sangat berpengaruh dalam hal ini adalah pengadukan dan pengendapan, yang juga mendapatkan pengaruh dari kecepatan arus dan kedalaman perairan. Pada perairan dangkal, proses resuspensi sedimen lebih tinggi, sehingga diduga logam berat yang ada dalam sedimen terlepas kembali ke kolom perairan (Maslukah, 2013).

Hasil pengukuran $\mathrm{Cu}^{2+}$ terlarut menyebutkan bahwa konsentrasi tertinggi didapatkan pada bagian permukaan. Hal ini menggambarkan bahwa sumber utama $\mathrm{Cu}$ berasal dari sungai ataupun dari udara yang mengandung partikulat $\mathrm{Cu}$ berupa debu yang terencerkan oleh air laut. Maslukah (2006) menyatakan bahwa proses masuknya $\mathrm{Cu}$ di perairan selanjutnya mengalami proses adsorpsi yang diikuti dengan proses flokulasi dan desorpsi. Adanya proses adsorpsi oleh partikel menyebabkan terjadinya pengendapan materi pada sedimen dan membuat konsentrasi di dekat dasar kolom air menjadi tinggi kembali.

Hasil Analisis Komponen Utama juga menunjukkan bahwa nilai salinitas merupakan nilai factor loading yang paling tinggi yaitu sebesar 0,906. Dari nilai ini dapat disimpulkan bahwa salinitas merupakan parameter yang paling berpengaruh di setiap lapisan kedalaman.

Untuk mengetahui korelasi kedalaman perairan serta parameter lingkungan seperti suhu, turbiditas, TSS, salinitas, $\mathrm{pH}$, dan $\mathrm{DO}$ terhadap konsentrasi $\mathrm{Cu}^{2+}$ dan $\mathrm{Hg}^{2+}$ terlarut, maka dilakukan analisis statistik menggunakan Korelasi Pearson. Nilai korelasi parameter lingkungan terhadap $\mathrm{Cu}^{2+}$ dan $\mathrm{Hg}^{2+}$ terlarut dapat dilihat pada Tabel 2.

Tabel 2. Hasil Korelasi Pearson

\begin{tabular}{lllllll}
\hline Variabel & Suhu & Turbiditas & Salinitas & $\mathrm{pH}$ & $\mathrm{DO}$ & $\mathrm{TSS}$ \\
\hline Suhu & 1 & -0.499 & -0.947 & 0.609 & 0.561 & 0.638 \\
Turbiditas & -0.499 & 1 & 0.514 & -0.829 & -0.928 & -0.239 \\
Salinitas & -0.947 & 0.514 & 1 & -0.638 & -0.583 & -0.607 \\
Ph & 0.609 & -0.829 & -0.638 & 1 & 0.970 & 0.182 \\
$\mathrm{DO}$ & 0.561 & -0.928 & -0.583 & 0.970 & 1 & 0.205 \\
$\mathrm{TSS}$ & 0.638 & -0.239 & -0.607 & 0.182 & 0.205 & 1 \\
$\mathrm{Cu}$ & 0.359 & 0.286 & -0.418 & 0.115 & -0.027 & 0.228 \\
$\mathrm{Hg}$ & -0.375 & -0.163 & 0.439 & -0.349 & -0.146 & 0.085 \\
\hline
\end{tabular}

Konsentrasi $\mathrm{Hg}^{2+}$ sangat berkorelasi signifikan dengan salinitas dan suhu dengan nilai $r$ masing-masing sebesar
0,439 dan $-0,375$. Hal ini menunjukkan bahwa semakin tinggi salinitas, semakin tinggi pula nilai $\mathrm{Hg}^{2+}$ serta semakin tinggi 
Syarifah Hikmah Julinda Sari, Jessica Feibe Ambar Kirana, Guntur. Analisis Kandungan Logam Berat Hg Dan Cu Terlarut Di Perairan Pesisir Wonorejo, Pantai Timur Surabaya

salinitas, semakin rendah nilai $\mathrm{Hg}^{2+}$. Suhu perairan yang tinggi dapat menyebabkan senyawa logam berat lebih mudah terlarut dalam air karena adanya penurunan laju adsorpsi ke dalam partikulat (Afriansyah, 2009).

Berdasarkan hasil analisis statistik tersebut dapat diketahui bahwa meter $\mathrm{Cu}^{2+}$ berkorelasi secara signifikant oleh salinitas dengan nilai $r$ sebesar $-0,418$ dan suhu sebesar 0,359. Hal ini menunjukkan bahwa semakin tinggi nilai salinitas, maka konsentrasi $\mathrm{Cu}^{2+}$ akan semakin rendah dan semakin tinggi suhu, semakin tinggi konsentrasi $\mathrm{Cu}^{2+}$ terlarut. Nilai $\mathrm{Cu}^{2+}$ pada kedalaman permukaan lebih tinggi dibandingkan pada kedalaman lainnya. Hal ini dikarenakan pada bagian permukaan, salinitas perairan cenderung rendah dikarenakan mendapat banyak pengaruh dari masukan Sungai Wonorejo. Menurut Nontji (1993), sebaran salinitas di lingkungan perairan dipengaruhi oleh beberapa faktor seperti pola sirkulasi air, penguapan, curah hujan dan aliran sungai. Namun perairan yang dekat dengan muara sungai mempunyai kisaran salinitas yang sangat dipengaruhi oleh air laut dan air tawar.

\section{KESIMPULAN}

Konsentrasi $\mathrm{Hg}$ dan $\mathrm{Cu}$ terlarut pada badan air Perairan Pesisir Wonerejo tergolong tinggi dimana berada di atas baku mutu yang telah ditetapkan. Konsentrasi logam berat tersebut berfluktuasi seiring dengan bertambahnya kedalaman. Konsentrasi $\mathrm{Cu}^{2+}$ terlarut cenderung semakin menurun seiring dengan pertambahan kedalaman dan kembali meningkat di dasar kolom air sedangkan konsentrasi $\mathrm{Hg}^{2+}$ terlarut semakin meningkat seiring dengan pertambahan kedalaman. Faktor lingkungan yang berpengaruh utama terhadap kehadiran logam berat $\mathrm{Hg}$ dan $\mathrm{Cu}$ terlarut pada badan air Pesisir Wonorejo adalah salinitas.

\section{DAFTAR PUSTAKA}

Afriansyah, Ardi. 2009. Konsentarasi Kadmium $(\mathrm{Cd})$ dan Tembaga $(\mathrm{Cu})$ dalam Air, Seston, Kerang dan Fraksinasinya dalam Sedimen di Perairan Delta Berau, Kalimantan Timur. Skripsi. Program Studi Ilmu dan Teknologi Kelautan. Fakultas Perikanan dan Ilmu Kelautan. IPB. Bogor.

APHA (American Public Health). 1998. Standard Methods for Examination of Water and Wastewater. 20 ${ }^{\text {th }}$ Edition. Washington DC.

Bengen, D. 2001. Pedoman Teknis Pengenalan dan Pengelolaan Ekosistem Mangrove. Pusat Kajian Sumberdaya Pesisir dan Lautan. IPB. Bogor

Effendi, H. 2003. Telaah Kualitas Air Bagi Pengelolaan Sumber Daya dan Lingkungan Perairan. Kanisius: Yogyakarta.

Guliyev, J. A., Hadjiyeva, S. R., Ghorbanpour, Sh., Aminbekov, A. F., Guseynli, A. G. 2014. Study of Vertical Distribution of Heavy Metals in the Border-Bottom Water in the Area of the Apsheron Peninsula. Int. J. of Bsc. Sc \& App. Rsch. 3 (9): 606-610.

Herdianto, Y. A., Lisyastuti, E., Najmiyati, E., Gani, Y. Y., 2003. Pengaruh Pemaparan $\mathrm{Cd}$ dan $\mathrm{Cu}$ Terhadap Abnormalitas Spermatozoa Ikan Mas (Cyprinus carpio, Linn). Universitas Padjadjaran : 
Sumedang. Jurnal Iktiologi Indonesia, Volume 3, Nomor 1, Juni 2003

Hutagalung, H. P., D. Setiapermana dan S. H. Riyono. 1997. Metode Analisis Air Laut, Sedimen dan Biota. Buku 2. Puslitbang Oseanologi. LIPI. 182 hal.

Marganof. 2007. Model Pengendalian Pencemaran di Danau Maninjau Sumatera Barat. IPB. Bogor.

Nontji, Anugerah. 2007. Laut Nusantara. Djambatan. Jakarta

Maslukah, Lilik. 2006. Konsentrasi Logam Berat $\mathrm{Pb}, \mathrm{Cd}, \mathrm{Cu}$ dan $\mathrm{Zn}$ dan Pola Sebarannya di Muara Banjir Kanal Barat, Semarang. Thesis. IPB. Bogor.

Maslukah, Lilik. 2013. Konsentrasi Logam Berat (Pb, Cd. Cu, Zn) Terlarut, dalam Seston, dan dalam Sedimen di Estuari Banjir Kanal Barat, Semarang. Akuatik-J. Sbdy. Perairan. 2 (1): 1-4.

Mokoagouw, Dolfie. 2000. Kajian Peredaran Logam Berat ( $\mathrm{Hg}, \mathrm{Cd}$, $\mathrm{Pb}, \mathrm{Cu}$, dan $\mathrm{Zn}$ ) pada Perairan Pantai di Kodya Bitung Propinsi Sulawesi Utara. Repository IPB. Bogor.

Patty, W., Tarumingkeng, Adrie. 2007. Variasi Temporal dari Penyebaran
Suhu di Muara Sungai Sario. J. I. Kelautan. 12 (2): 73-78.

Sunarto. 2008. Peranan Cahaya dalam Proses Produksi di Laut. Karya Ilmiah. Universitas Padjadjaran. Bandung.

Saputra, H. K. 2009. Karakteristik Kualitas Air Muara Sungai Cisadane Bagian Air Tawar dan Payau di Kabupaten Tangerang, Banten. Skripsi. Fakultas Perikanan dan Ilmu Kelautan. IPB. Bogor.

Surbakti. 2011. Analisis Logam Berat Kadmium (Cd), Cuprum (Cu), Kromium (Cr), Ferrum (Fe), Nikel (Ni), Zinkung (Zn) pada Sedimen Muara Sungai Asahan di Tanjung Balai dengan Metode Spektrofotometri Serapan Atom (SSA). Thesis. Universitas Sumatera Utara. Medan. (Tidak diterbitkan)

Taftazani, Agus. 2007. Distribusi Konsentrasi Logam Berat $\mathrm{Hg}$ dan $\mathrm{Cr}$ pada Sampel Lingkungan Perairan Surabaya. Prosiding PPI PDIPTN. Pustek Akselerator dan Proses Bahan. Yogyakarta.

Vangronsveld, J., Clijsters, H., 1994. Toxic effects of metals, in: Plants and the Chemical Elements: Biochemistry, Uptake, Tolerance and Toxicity. VCH Publishers, Weinheim, pp. 150-177. 